\title{
Permeability of Different Groups of Maxillary Teeth after 38\% Hydrogen Peroxide Internal Bleaching
}

\author{
Lívia Maria RODRIGUES ${ }^{1}$ \\ Luis Pascoal VANSAN ${ }^{1}$ \\ Jesus Djalma PÉCORA² \\ Melissa Andréia MARCHESAN ${ }^{1}$ \\ ${ }^{1}$ Department of Endodontics, Dental School, University of Ribeirão Preto, Ribeirão Preto, SP, Brazil \\ ${ }^{2}$ Department of Restorative Dentistry, Dental School of Ribeirão Preto, University of São Paulo, Ribeirão Preto, SP, Brazil
}

\begin{abstract}
This study evaluated the influence of internal tooth bleaching with $38 \%$ hydrogen peroxide $\left(\mathrm{H}_{2} \mathrm{O}_{2}\right)$ on the permeability of the coronal dentin in maxillary anterior teeth and premolars. Seventy teeth (14 per group) were used: central incisors (CI), lateral incisor (LI), canines (C), first premolars (1PM) and second premolars (2PM). Pulp chamber access and transversal sectioning at $2 \mathrm{~mm}$ from the cementoenamel junction were performed and the specimens were divided into 2 groups $(n=7)$ : a) no treatment and b) bleaching with $38 \% \mathrm{H}_{2} \mathrm{O}_{2}$. The bleaching agent was applied to the buccal surface and to the pulp chamber for 10 min. This procedure was repeated 3 times. The specimens were processed histochemically with copper sulfate and rubeanic acid, sectioned longitudinally, and digitalized in a scanner. The area of stained dentin was measured using Image Tool software. Data were analyzed statistically by ANOVA and Tukey's HSD test $(\alpha=0.05)$. There was statistically significant difference $(p<0.001)$ among the untreated groups, CI $(0.23 \pm 0.26)$ having the lowest permeability and LI (10.14 \pm 1.89$)$ the highest permeability. Among the bleached groups, dentin permeability was increased in all groups of teeth except for 2PM. It may be concluded that bleaching with $38 \% \mathrm{H}_{2} \mathrm{O}_{2}$ affected dentin permeability near the pulp chamber in maxillary anterior teeth and in first and second premolars.
\end{abstract}

Key Words: dentin permeability, hydrogen peroxide, bleaching.

\section{INTRODUCTION}

Discoloring of endodontically treated teeth is caused by intrinsic changes such as intrapulpal hemorrhage, products of tissue decomposition, inadequate coronary access that maintains chromophore materials inside the pulp chamber, and/or obturation materials remaining in the pulp chamber due to incorrect cavity cleaning and dressing placement $(1,2)$.

The main substances used for bleaching endodontically treated teeth are sodium hypochlorite, hydrogen peroxide at different concentrations, carbamide peroxide (also known as urea peroxide) and sodium perborate (pure or diluted), which can be used alone or associated $(3,4)$.

Regardless of the product of choice, bleaching agents act by an oxireduction reaction with the darkened substrate $(4,5)$. This reaction modifies the darkened molecules inside dentin and can restore original color. According to Kawamoto and Tsujimoto (1) bleaching agents must have low molecular weight in order to penetrate into dentin and enamel and totally or partially remove pigments. The success of bleaching procedures is directly related to the transdentinal penetration of these bleaching agents.

Dentin is composed by dentinal tubules that are formed due to mineralized matrix deposition of predentin around odontoblasts during dentinogenesis, which gives this tissue permeability (6). This permeability varies according to the number and the diameter of the tubules in each region of the crown or root and results in important property variations throughout the dentin $(6,7)$. The number and diameter of tubules increase near the pulp chamber in the tooth crown. According to Marshall (8), structural organization and micro-structural variations reflect formative influences, such as tooth

Correspondence: Profa. Dra. Melissa Andréia Marchesan, Rua Pau Brasil, 310, Jardim Recreio, Ribeirão Preto, SP, Brasil. Tel/Fax: +55-16-36307986. e-mail:meljul@uol.com.br 
size, shape, and type.

Dozic et al. (9) studied the strength of color relation among the maxillary central incisor, lateral incisor and canine teeth and established stronger relation in color between incisors and canines at the cervical third than between the middle and incisal segments.

Therefore, the aims of the present study were to quantify the penetration of $38 \%$ hydrogen peroxide into pulp chamber dentin after internal bleaching and determine the permeability of the crowns of different groups of teeth.

\section{MATERIAL AND METHODS}

Seventy human maxillary teeth (14 central incisors, 14 lateral incisors, 14 canines, 14 first and 14 second premolars) were washed in running water for $24 \mathrm{~h}$ and examined under $\times 20$ stereomicroscope magnification (Leica Microsystems, Wetzlar, Germany) to exclude those with fracture lines, fissures and incisal/ occlusal wear.

Access to the pulp chambers was done considering the anatomical aspects of each group of teeth. Teeth were cut transversally at $2 \mathrm{~mm}$ from the cementoenamel junction towards the root using a diamond disc (KG Sorensen, Barueri, SP, Brazil).

The specimens of each group of teeth were divided into 2 groups $(n=7)$ and placed in an acrylic apparatus to keep the crown perpendicular to the surface. One group received no treatment and the other groups receive internal bleaching with $38 \%$ hydrogen peroxide (Opalescence Xtra Boost; Ultradent Products Inc., South Jordan, UT, USA). The gel was used according to the manufacturer's instructions to the buccal surface and inside the pulp chamber: application, aspirated after 10 $\mathrm{min}$, and rising of the bleached surfaces with water. This sequence of procedures was repeated 3 times.

Specimens were washed in running water for 10 min and then immersed in 10\% copper sulfate aqueous solution (Merck, Darmstadt, Germany) for $30 \mathrm{~min}$, in a vacuum for the first $5 \mathrm{~min}$, dried with paper points (Dentsply/Maillefer, Ballaigues, Switzerland), and placed in $1 \%$ rubeanic acid alcohol solution (Merck) for $30 \mathrm{~min}$, in a vacuum for the first $5 \mathrm{~min}$. The reaction of these 2 chemicals forms a stained compound ranging in color from deep blue to black, depending on the quantity of copper ions present. Teeth were kept in closed jars with ammonium-embedded cotton pellets for color fixation.

On completion of this reaction, each specimen was fixed with green sculpture wax (Odontofix, Ribeirão Preto, SP, Brazil) on an $8 \times 4 \mathrm{~mm}$ acrylic plate at the palatal surface to ensure standardization during sectioning. A single buccal-palatal cut was done in a cutting machine with a diamond disc under constant irrigation with water to prevent dentin burn.

The specimens were positioned with the cut side down on a flat-bed scanner (HP Scanjet G2710, Palo Alto, CA, USA) and scanned at 1400 dpi under standardized lighting conditions, distance and exposure. Stain penetration analysis was preformed using the Image Tool Software (http://ddsdx.uthsca.edu/dig/ itdesc.html; UTHSCSA, San Antonio, TX, USA). This software enables the measurement of the total area of dentin, at the buccal and palatal sides of the crown, and the measurement of the stained area. The area of stained dentin is reported as a percentage of the total visible dentin for all tooth groups.

The results of the percentage stained area was analyzed for the permeability of the entire crown and for the comparison of copper ion penetration on buccal and palatal surfaces. ANOVA was followed by the Tukey's HSD test and significance was set at 5\% (17.0 SPSS for Windows, Chicago, IL, USA).

\section{RESULTS}

Penetration of copper ions on the total dentin surface of the crown of each group is reported in Table 1.

When the teeth were not bleached, there was no statistically significant difference $(p>0.05)$ between the central incisors and canines. The lateral incisors presented the highest permeability and premolars presented intermediate permeability values $(\mathrm{p}<0.001)$. When the teeth were bleached, there was a statistically signifi-

Table 1. Penetration (mean \pm SD) of copper ions into the pulp chamber dentin in different groups of maxillary teeth (\%).

\begin{tabular}{lrr}
\hline & No treatment & \multicolumn{1}{c}{ Bleached } \\
\hline Central incisors & $0.23 \pm 0.26$ & $13.23 \pm 1.82$ \\
Lateral incisors & $10.14 \pm 1.89$ & $13.73 \pm 2.70$ \\
Canines & $2.98 \pm 1.00$ & $16.15 \pm 1.92$ \\
1st premolars & $7.27 \pm 1.29$ & $14.15 \pm 4.14$ \\
2nd premolars & $6.74 \pm 0.73$ & $9.58 \pm 2.94$ \\
\hline
\end{tabular}


cant increase in the permeability for all groups of teeth $(\mathrm{p}<0.001)$, except for the second premolars, which were statistically similar to their untreated group $(\mathrm{p}>0.05)$.

Permeability of the buccal and palatal surfaces was statistically similar ( $p>0.05)$ for all groups of teeth, comparing each group individually and subjected to the same treatment (bleached or not), except for the first premolars, which presented significantly $(p>0.01)$ higher copper ion penetration values at the buccal surface $(9.65$ $\pm 2.34)$ compared to the palatal surface $(4.50 \pm 2.47)$.

\section{DISCUSSION}

In the present study, care was taken during the methodological phase and must be explained. The histochemical method proposed by Pécora et al. (10) was used to detect dentin permeability because of the reproducibility of this method, smaller molecule size of copper ions compared to organic dyes, and insolubility of copper in xylol allowing clearing of dentin without staining. Since Pashley and Livingston (11) published their findings on the effect of molecular size on permeability coefficients in human dentin, in 1978, it is known that the size of the molecule is fundamental when detecting dentin permeability. Those authors reported that an increase of 19 times in molecule size would decrease permeability 100 times. It is also important to acknowledge that the rubeanic acid reveals copper ions forming a stained compound ranging in color from deep blue to black. This depends on the amount of copper ions present, with a limit for identification of copper at 0.006 $\mu \mathrm{g}$, which shows the sensitivity of the method. Using the same methodology, Carrasco et al. (12) showed that different bleaching agents can increase the permeability of the coronal dentin of endodontically treated teeth.

In the present study, the pulp chamber was irrigated with only distilled and deionized water to not induce chemical changes in dentin (13) and verify permeability changes induced only by the bleaching agent.

The teeth used in this study did not present incisal/ occlusal wear. Mechanical wear produced by mastication and/or parafucntional habits can induce the formation of tertiary or reactionary dentin, which presents unorganized and obliterated dentinal tubules (7). Changes in dentin, including irregular secondary dentin formation, affect the permeability of the tissue and can influence results due to incapacity or diminishing of the penetration of hydrogen peroxide into dentin. According to Prati (14) considering the formula postulated by Poiseuille-Hagen, small functional alterations in the diameter of the dentin tubules can accentually modify permeability.

Hydrogen peroxide is a strong oxidizing agent that can act on dentin modifying its mechanical and chemical properties. The bleaching mechanism of hydrogen peroxide has not yet been fully established and some controversy exists. Hydrogen peroxide is able to generate hydroxyl radical $\left(\mathrm{OH}^{-}\right)$in the presence of ferrous salts, which has been described as being responsible for dental bleaching. Due to its high oxidation potential, $\mathrm{OH}^{-}$radicals act in intertubular and peritubular dentin breaking the polypeptide chains and degrading components of connective tissue, particularly collagen and hyaluronic acid, thereby attacking the organic component of dentin. These ultra-structural alterations increase dentin permeability and reduce hardness and elasticity $(12,15)$.

Carrasco-Guerisoli et al. (15) reported that both low $\mathrm{pH}$ and hydrogen peroxide oxidation play a role in altering the ultra-structure of dentin during internal dental bleaching. Different brands of bleaching agents can have an acid or alkaline $\mathrm{pH}$. Opalescence Xtra, is highly acidic, with a pH of 3.67 (16) and, under scanning electron microscopy, showed a more irregular pattern on dentin, with shallow erosion areas covering the sample surface. In a previous study (3), this product led to a $22 \%$ reduction of microhardness for dentin.

The penetration of the copper ions into the different regions of the crown after dental bleaching with $38 \%$ hydrogen peroxide showed a uniform transposition of copper ions at the cervical, middle and incisal thirds, with regard to the natural dentin thickness. According to Haywood (17), this could have occurred due to the rapid penetration of the bleaching agent into the dentin because the crowns were not stained previously. The lack of interference in the tubule allowed hydrogen peroxide to penetrate evenly throughout the crown.

The penetration of copper ions followed a similar pattern at the buccal and palatal sides, except for the first premolars, which showed a higher penetration at the buccal side $(9.65 \pm 2.34)$ compared to the palatal side $(4.50 \pm 2.47)$. These results do not agree with those of Sulieman et al. (18) who observed lack of bleaching on the palatal region after use of $35 \%$ hydrogen peroxide. This resul, though, was not explained by the authors.

The variation of permeability in the different groups of teeth showed that the central incisors had the lowest values $(0.23 \pm 0.26)$ of copper ion infiltration. 
However, after bleaching with 38\% hydrogen peroxide, permeability increased significantly $(13.23 \pm 1.82)$ and was similar to that of the other groups of bleached teeth, which were statistically similar to each other $(p>0.05)$, except for the second premolars, which were the only group of teeth that presented no significant increase in permeability after bleaching ( $\mathrm{p}>0.05)$.

The present study analyzed the behavior of different groups of teeth exposed to $38 \%$ hydrogen peroxide. The obtaiend results open perspectives for new research involving endodontic rehabilitation in order to verify the influence of the type, shape and function of the treated tooth, simulating as closes as possible the clinical reality.

\section{RESUMO}

Este estudo avaliou a influência do clareamento interno com peróxido de hidrogênio $\left(\mathrm{H}_{2} \mathrm{O}_{2}\right)$ a $38 \%$ na permeabilidade da dentina coronária de dentes anteriores superiores e pré-molares superiores. Quatorze incisivos centrais (IC), incisivos laterais (IL), caninos (C), primeiros (1PM) e segundos (2PM) pré-molares foram seccionados transversalmente e distribuídos em 2 grupos $(n=7)$ sendo: G1: não receberam tratamento e, G2: clareados com aplicação de gel na face vestibular e câmara pulpar por 10 min, repetido 3 vezes. Os espécimes foram processados histoquimicamente por meio de imersão em sulfato de cobre e ácido rubeânico e digitalizados em escaner. A área corada foi aferida (Programa Image Tool). Os dentes que não receberam tratamento, apresentaram diferença estatisticamente significante $(\mathrm{p}<0,001)$, sendo o ICS $(0,23 \pm 0,26)$ e o ILS $(10,14 \pm 1,89)$ os grupo com os menores e os maiores valores de permeabilidade, respectivamente. Quando clareados, a permeabilidade coronária dos grupos dentais foi aumentada, exceto no grupo do 2PM. Concluiu-se que a permeabilidade da dentina coronária nos dentes anteriores superiores e primeiros pré-molares foi alterada pelo clareamento dental interno.

\section{REFERENCES}

1. Kawamoto K, Tsujimoto Y. Effects of the hydroxyl radical and hydrogen peroxide on tooth bleaching. J Endod 2004;30:45-50.

2. Plotino G, Buono L, Grande NM, Pameijer CH, Somma F.
Nonvital tooth bleaching: a review of the literature and clinical procedures. J Endod 2008;34:394-407.

3. Lewinstein I, Fuhrer N, Churaru N, Cardash H. Effect of different peroxide bleaching regimens and subsequent fluoridation on the hardness of human enamel and dentin. J Prosthet Dent 2004;92:337-342.

4. Pobbe POS, Viapiana R, Souza-Gabriel AE, Marchesan MA, Sousa-Neto MD, Silva-Sousa YTC, et al.. Coronal resistance to fracture of endodontically treated teeth submitted to light-activated bleaching. J Dent 2008;36:935-939.

5. Joiner A. Teeth bleaching: a review of the literature. J Dent 2006;34:412-419.

6. Pashley DH. Dentin-predentin complex and its permeability: physiologic overview. J Dent Res 1985;64:613-620.

7. Mjör IA. Dentin permeability: the basis for understanding pulp reactions and adhesive technology. Braz Dent J 2009;20:3-16.

8. Marshall GW. Dentin: microstructure and characterization. Quintessence Int 1993;24:606-617.

9. Đozic A, Kleverlaan CJ, Aartman IHA, Feilzer AJ. Relation in color among maxillary incisors and canines. Dent Mat 2005;21:187191.

10. Pécora JD, Costa WF, Campos GM, Roselino RB. Presentation of a histochemical method for the study of root dentine permeability. Rev Odontol Univ São Paulo 1987;1:3-9.

11. Pashley DH, Livingston MJ. Effect of molecular size on permeability coefficients in human dentine. Arch Oral Biol 1978;23:391395.

12. Carrasco LD, Guerisoli DMZ, Pécora JD, Fröner IC. Evaluation of dentin permeability after light activated internal dental bleaching. Dent Traumatol 2007;23:30-34.

13. Sim TP, Knowles JC, Ng YL, Shelton J, Gulabilava K. Effect of sodium hypochlorite on mechanical properties of dentine and tooth surface strength. Int Endod J 2001;34:120-132.

14. Prati C. What is the clinical relevance of in vitro dentine permeability tests? J Dent 1994;22:83-88.

15. Carrasco-Guerisoli LD, Shiavoni RJS, Barroso JM, Guerisoli DMZ, Pécora JD, Fröner IC. Effect of different bleaching systems on the ultrastructure of bovine dentin. Dent Traumatol 2009;25:176-180.

16. Price RB, Sedarous M, Hiltz GS. The $\mathrm{pH}$ of tooth-whitening products. J Can Dent Assoc 2000;66:421-426.

17. Haywood VB. Achieving, maintaining, and recovering successful tooth bleaching. J Esthet Dent 1996;8:31-38.

18. Sulieman M, Addy M, MacDonald E, Rees JS. The bleaching depth of a $35 \%$ hydrogen peroxide based in-office product: a study in vitro. J Dent 2005;33:33-40. 